\title{
ИНФОРМАЦИЯ / INFORMATION
}

\author{
Н. В. ЩЕДРИН ${ }^{1}$ \\ И. А. ДАММ ${ }^{1}$ \\ Е. А. АКУНЧЕНКО 1 \\ ${ }^{1}$ Сибирский федеральный университет, г. Красноярск, Россия

\section{АКТУАЛЬНЫЕ ПРОБАЕМЫ АНТИКОРРУПЦИОННОГО ПРОСВЕЩЕНИЯ И АНТИКОРРУПЦИОННОГО ОБРАЗОВАНИЯ}

Цель: ознакомление широкого круга заинтересованных лиц с результатами работы ІІ Сибирского антикоррупционного форума с международным участием «Актуальные проблемы антикоррупционного просвещения и антикоррупционного образования», состоявшегося 15-16 сентября 2016 г. в Сибирском федеральном университете (г. Красноярск). Методы: при подготовке своих выступлений участники форума использовали общенаучный метод диалектического познания, а также ряд частнонаучных методов: историко-юридический, системно-структурный, сравнительно-правовой, формально-логический (дедукции, индукции, определения и деления понятия) и др.

Результаты: выработка предложений по совершенствованию антикоррупционного просвещения и антикоррупционного образования. В работе форума приняли участие проректор по социальным вопросам СФУ д-р экон. наук, профессор С. И. Мутовин, директор Юридического института СФУ, д-р юрид. наук, профессор И. В. Шишко, руководитель отдела исследования и развития Международного института планирования образования ЮНЕСКО (Франция), доктор философии в области образования М. Пуассон, заведующий кафедрой деликтологии и криминологии Юридического института СФУ, д-р юрид. наук, профессор Н. В. Щедрин, директор Центра антикоррупционных технологий (г. Томск), канд. юрид. наук С. М. Будатаров, начальник Центра по изучению российского права, профессор Хэйлунцзянского университета г. Харбина (Китай), канд. юрид. наук Пан Дунмэй, директор Центра противодействия коррупции и правовых экспертиз СФУ, доцент кафедры деликтологии и криминологии Юридического института СФУ, канд. юрид. наук, И. А. Дамм, а также представители органов государственной власти, местного самоуправления, институтов гражданского общества, средств массовой информации.

Научная новизна: на площадке форума состоялось комплексное научно-практическое обсуждение ключевых вопросов формирования в обществе нетерпимости к коррупционному поведению при помощи антикоррупционного просвещения и антикоррупционного образования.

Практическая значимость: в ходе состоявшейся научно-практической дискуссии участниками форума выдвинут ряд предложений по совершенствованию правового регулирования и организации антикоррупционного просвещения и антикоррупционного образования с учетом накопленного опыта, в том числе и зарубежных стран.

Ключевые слова: коррупция; противодействие коррупции; профилактика коррупции; антикоррупционное просвещение; антикоррупционное образование; образовательные организации; система образования

Как цитировать статью: Щедрин Н. В., Дамм И. А., Акунченко Е. А. Актуальные проблемы антикоррупционного просвещения и антикоррупционного образования // Актуальные проблемы экономики и права. 2017. Т. 11, № 3. C. 153-166. DOI: http://dx.doi.org/10.21202/1993-047X.11.2017.3.147-160 


\author{
N. V. SHCHEDRIN ${ }^{1}$ \\ I. A. DAMM ${ }^{1}$ \\ E. A. AKUNCHENKO ${ }^{1}$ \\ ${ }^{1}$ Siberian Federal University, Krasnoyarsk, Russia
}

\title{
TOPICAL ISSUES OF ANTICORRUPTION ENLIGHTENMENT AND ANTICORRUPTION EDUCATION
}

Objective: to familiarize a wide range of interested persons with the results of the 2nd Siberian Anti-corruption Forum with international participation "Topical issues of anti-corruption enlightenment and anti-corruption education" held on 15-16 September 2016 at the Siberian Federal University (Krasnoyarsk).

Methods: in the preparation of their presentations, the forum participants used the scientific method of dialectical cognition, and a number of specific scientific methods: historical-legal, systemic-structural, comparative legal, formal logic (deduction, induction, definition and division of concepts), etc.

Results: elaboration of proposals on improvement of anti-corruption enlightenment and anti-corruption education. In the forum took part the Vice-rector for social Affairs of SFU, Doctor of Economics, Professor S. I. Mutovin, Director of the Law Institute of SFU, Doctor of Law, Professor I. V. Shishko and Head of Research and Development Department of International Institute for Educational Planning, UNESCO (France), PhD in Education M. Poisson, Head of the Department of Delictology and Criminology of the Law Institute of SFU, Doctor of Law, Professor N. V. Shchedrin, Director of the Center for anti-corruption technologies (Tomsk), PhD in Law S. M. Budatarov, Head of the Center for the Russian Law Studies, Professor of the Heilongjiang University of Harbin (China), PhD in Law Pan Dunmay, Director of the Center for combating corruption and legal expertise of SFU, Associate Professor of the Deparment of Delictology and Criminology of the Law Institute of SFU, PhD in Law I. A. Damm, as well as representatives of public authorities, local governments, civil society institutions, and mass media.

Scientific novelty: the forum held interdisciplinary scientific-practical discussion of the key issues of formation of public intolerance towards corruption behavior by means of anti-corruption enlightenment and anti-corruption education.

Practical significance: in the ensued scientific discussion, the forum participants put forward a number of proposals for improvement of legal regulation and organization of anti-corruption enlightenment and anti-corruption education in the light of the accumulated experience, including in foreign countries.

Keywords: Corruption; Corruption counteraction; Prevention of corruption; Anti-corruption enlightenment; Anti-corruption education; Educational organization; Educational system

For citation: Shchedrin N. V., Damm I. A., Akunchenko E. A. Topical issues of anticorruption enlightenment and anticorruption education, Actual Problems of Economics and Law, 2017, vol. 11, No. 3, pp. 153-166 (in Russ.). DOI: http://dx.doi. org/10.21202/1993-047X.11.2017.3.147-160

\section{Введение}

Формирование в обществе нетерпимости к коррупционному поведению входит в число приоритетных задач государственной антикоррупционной политики и в соответствии со ст. 6 Федерального закона «О противодействии коррупции» ${ }^{1}$ является первоочередной

О противодействии коррупции: Федеральный закон № 273-ФЗ от 25.12.2008 // Собрание законодательства РФ. 2008. № 52. Ч. 1. Ст. 6228. мерой по профилактике коррупции. Вопрос о наиболее эффективных методах указанной деятельности на сегодняшний день остается открытым. Вместе с тем анализ федеральных, региональных и муниципальных нормативных правовых актов, программных документов, правоприменительной практики и актуальных исследований в области юриспруденции, социологии, психологии, педагогики, экономики, политологии и других гуманитарных наук свидетельствует о том, что главными претендентами на данную роль явля-

Щедрин Н. В., Дамм И. А., Акунченко Е. А. Актуальные проблемы антикоррупиионного просвещения и антикоррупиионного образования Shchedrin N. V., Damm I. A., Akunchenko E. A. Topical issues of anticorruption enlightenment and anticorruption education 
ются антикоррупционное просвещение и антикоррупционное образование.

Изучению актуальных вопросов организации просветительской и образовательной деятельности антикоррупционного содержания посвящены труды многих специалистов: Р. А. Абрамова [1], И. И. Бикеева [2], С. А. Воронцова [3], И. М. Гарипова [4], Ю. П. Гармаева [5], 3. 3. Зинатуллина [6], П. А. Кабанова [7-14], Е. Б. Козловой [15], Т. Г. Слюсаревой [16], Н. В. Сюзевой [17], Ю. В. Трунцевского [18], В. А. Фалилеева [19], Л. Р. Хайрутдиновой [20, 21], М. В. Шедий [22], Е. С. Шугриной [23], М. Р. Юсупова [24] и др. И, как указывает большинство авторов, рассматриваемые антикоррупционные инструменты достаточно сложны в своей реализации, в связи с чем требуют особого внимания со стороны общества и государства.

\section{Результаты форума}

В целях активизации научно-практического диалога и консолидации усилий различных субъектов противодействия коррупции в указанной сфере 15-16 сентября 2016 г. в Сибирском федеральном университете (далее - СФУ) состоялся II Сибирский антикоррупционный форум с международным участием «Актуальные проблемы антикоррупционного просвещения и антикоррупционного образования», организаторами которого выступили Юридический институт и Центр противодействия коррупции и правовых экспертиз СФУ, Администрация Губернатора Красноярского края, Министерство образования Красноярского края, а также Гражданская ассамблея Красноярского края. Участие в форуме приняли более 180 представителей государственных и муниципальных органов, правоохранительных органов, образовательных и общественных организаций, студентов и иных активных представителей гражданского общества.

С приветственным словом к участникам и гостям форума обратились:

И. А. Жуков - исполняющий полномочия начальника управления Губернатора Красноярского края по безопасности, профилактике коррупционных и иных нарушений;

С. И. Мутовин - д-р экон. наук, профессор, проректор по социальным вопросам СФУ;

И. В. Шишко - д-р юрид. наук, профессор, директор Юридического института СФУ;
В. А. Суроткин - член Совета Гражданской ассамблеи Красноярского края, председатель правления Красноярского регионального фонда поддержки патриотического воспитания «Держава».

Основной темой первого дня работы форума стали общие вопросы организации антикоррупционного просвещения и антикоррупционного образования. С докладами в рамках пленарного заседания выступили признанные эксперты.

Особенности антикоррупционного образования за рубежом представила М. Пуассон, руководитель отдела исследования и развития Международного института планирования образования ЮНЕСКО, руководитель исследовательского проекта «Этика и коррупция в образовании», доктор философии в области образования (Университет Пикардии им. Ж. Верна, Франция). Антикоррупционное образование, с точки зрения г-жи Пуассон, заключается в создании, восстановлении доверия, социальной справедливости как среди отдельных лиц, так и организаций, а также в выработке культуры беспристрастности и неподкупности во имя общественного блага. Говоря о нем, необходимо понимать, что есть по меньшей мере три важных аспекта антикоррупционной образовательной деятельности, которые нельзя упускать из внимания: распространение знаний о существующем антикоррупционном законодательстве; развитие навыков разрешения сложных коррупциогенных ситуаций; формирование системы ценностей и нравственных установок антикоррупционного содержания.

В своем докладе г-жа Пуассон подчеркнула, что круг субъектов антикоррупционного образования, его содержание и методы достаточно разнообразны и варьируются в зависимости от политической воли отдельного государства либо от сферы деятельности и финансового состояния конкретной организации. В свою очередь, существующие в Европе программы подготовки могут быть сведены к трем основным формам. Первый подход ориентирован на соблюдение персоналом нормативных предписаний и этических кодексов, для того чтобы исключить возникновение коррупционных ситуаций в практической деятельности, и выражается в распространении антикоррупционной информации. Второй подход является ценностно ориентированным и предполагает решение конкретных задач, составленных на основе распространенных коррупциогенных ситуаций (например, 
получение подарка государственным служащим). Третий подход сфокусирован на «серых» зонах, т. е. вопросах, не урегулированных законодательством, ситуациях конфликта интересов, этических рисков и др.

Кроме того, г-жа Пуассон озвучила основные проблемы, способствующие снижению эффективности антикоррупционного образования. К их числу следует отнести: необязательность соответствующей подготовки; отсутствие зависимости между подготовкой и оценкой эффективности работы сотрудника; отсутствие реальной политической поддержки со стороны руководства; низкое качество подготовки либо ситуация, когда качество подготовки не является низким, но и не является практикоориентированным и др.

В заключение докладчиком были рассмотрены успешные практики реализации антикоррупционных образовательных программ некоторыми государственными и неправительственными организациями. Предметно с ними можно ознакомиться в издании Международного института планирования образования ЮНЕСКО «Коррумпированные школы, коррумпированные университеты: Что можно сделать?» [25].

Прокурор Красноярского края, государственный советник юстиции 2-го класса М. М. Савчин представил участникам форума опыт органов прокуратуры в осуществлении антикоррупционного просвещения и антикоррупционного образования. По мнению докладчика, к числу наиболее действенных способов просвещения следует отнести проведение семинаров, консультаций и круглых столов. Особую эффективность они приобретают в том случае, когда проводятся в ведомстве или организации на основе рассмотрения и разбора нарушений, выявленных в ходе проверочных мероприятий в этом в ведомстве или организации.

В течение 2015-2016 гг. прокуроры приняли участие в 255 мероприятиях просветительского характера, организованных как по собственной инициативе, так и по инициативе органов государственной власти и местного самоуправления. Особое внимание органами прокуратуры края уделяется антикоррупционному просвещению в образовательных учреждениях края. В целях обеспечения принципа публичности и открытости деятельности органами прокуратуры края широко используются возможности средств массовой информации. За последние два года подготовлено около 2000 публикаций о работе органов прокуратуры в сфере противодействия коррупции, многие из них вызвали широкий общественный резонанс.

В заключение прокурор края подчеркнул, что успех антикоррупционной деятельности зависит, прежде всего, от уровня правовой культуры граждан, но привить его в короткое время не представляется возможным. Антикоррупционное мировоззрение необходимо формировать не с университетской скамьи, а начиная с раннего детства. Для изменения существующей ситуации в условиях нетерпимости к коррупционному поведению должно вырасти не одно поколение граждан Российской Федерации. Дальнейшая реализация органами прокуратуры края антикоррупционных просветительских мер окажет положительное влияние на формирование в обществе устойчивых антикоррупционных стандартов поведения.

Н. В. Щедрин, д-р юрид. наук, профессор, заведующий кафедрой деликтологии и криминологии Юридического института СФУ, посвятил свое выступление актуальным проблемам антикоррупционного просвещения в Российской Федерации. В целях иллюстрации докладчик представил коррупцию в виде «сорняка», от борьбы с которым зачастую страдают полезные «злаки», и особо отметил, что за прошедшие с момента принятия Федерального закона «О противодействии коррупции» годы граждане так и не научились их отличать.

До недавнего времени под коррупцией в России понимали, главным образом, взяточничество. В последние годы в коррупционный ряд стали включать еще и злоупотребления служебным положением, которое сопряжено с извлечением явной материальной выгоды. Очевидно, что все это - лишь наиболее «контрастные» проявления коррупции в жизни общества, которые социологи зачастую окрашивают в черный цвет [26]. Но не менее опасны и более тусклые формы - «серая» и «белая» коррупция. К последней, в частности, причисляются деяния, которые как коррупционные вообще не воспринимаются. Такие явления, как «клиентелизм» (в русской интерпретации - «блат», от немецкого blatt - листок, на котором передавалась просьба приближенного), «фаворитизм», «протекционизм», с коррупцией в головах большинства наших соотечественников не ассоциируются. Они, по сути дела, интегрированы в культуру российского общества. 
Поэтому у населения формируется модель противодействия коррупции, в которой главная роль принадлежит наказанию, и в первую очередь уголовному. Подобный подход подобен борьбе с сорняками посредством их скашивания, а если еще точнее - избирательного скашивания. Но любой сельский житель или дачник знает, что сорняки надо вырывать все подряд, и лучше всего с корнем. А еще более продвинутый земледелец знает, что успех в борьбе с сорняками определяют правильный севооборот, умелая агротехническая обработка почвы. Самые действенные антикоррупционные механизмы - это реальное народовластие, разделение властей, их прозрачность, свобода слова, свобода массовой информации, идеологическое многообразие, реальная многопартийность, добросовестная конкуренция в экономической и политической сферах. Все это четко прописано в Конституции Российской Федерации. И наоборот, благоприятные условия для «коррупционных всходов» создает отступление от принципов «демократического федеративного, правового государства с республиканской формой правления» (ст. 1 Конституции РФ²). Именно на этих простых вещах необходимо акцентировать внимание при проведении антикоррупционного просвещения. В противном случае эта деятельность неизбежно превратится в борьбу с ветряными мельницами.

Основная задача антикоррупционного просвещения состоит в том, чтобы обеспечить преодоление сложившихся в обществе стереотипов о коррупции и борьбе с ней, сформировать у большинства граждан системное представление об истинных причинах коррупции. «Мы сами порождаем коррупцию, именно поэтому задача антикоррупционного просвещения и образования - разбудить совесть каждого члена общества», - подчеркнул Н. В. Щедрин.

О роли следственных органов в формировании антикоррупционного правосознания рассказал А. Ю. Расстрыгин, первый заместитель руководителя Главного следственного управления Следственного комитета Российской Федерации по Красноярскому

2 Конституция Российской Федерации: принята всенародным голосованием 12 декабря 1993 г. (с учетом поправок, внесенных законами РФ о поправках к Конституции РФ № 6-ФКЗ от 30.12.2008, № 7-ФКЗ от 30.12.2008, № 2-ФКЗ от 05.02.2014, № 11-ФКЗ от 21.07.2014) // Собрание законодательства РФ. 2014. № 31 . Ст. 4398 . краю, полковник юстиции. Докладчик отметил, что вопросы противодействия коррупции являются приоритетными в деятельности органов Следственного комитета Российской Федерации. Наиболее выявляемыми являются факты взяточничества в сфере образования и здравоохранения. В 2016 г. расследовано 53 таких преступления. Зачастую лица, получающие (передающие) взятку, не отдают себе отчет, что какой бы незначительной она ни была, это уголовно наказуемое деяние. Это так называемая бытовая коррупция. Не следует принижать значение противодействия ей, ошибочно полагая, что в силу мелочности она не несет в себе значительного вреда. Бытовая коррупция является всеобъемлющей, вызывает привыкание на ментальном уровне, деформируя сознание человека с раннего возраста. Ребенок, услышав от матери укор за плохое поведение в детском садике, где место получено за кругленькую сумму, с детства постигает негласные правила взрослой игры, соблюдение которых позволяет получить заветное. Студент, передавая взятку за зачет, свои мысли обращает к будущему возврату вложенного в коррупцию тем же незаконным путем. В обществе, где коррупция вызывает ощущение нормы, формируется замкнутая система теневых отношений. Взятка в таком обществе становится главной движущей силой, этаким «магическим кристаллом». И порой не имеет значения, какой используется эквивалент - борзые щенята, махорка или фантики. Так, приговором Советского районного суда осужден руководитель физического воспитания среднего специального образовательного учреждения, обвиняемый в получении трех взяток от обучающихся за проставление отметок о зачете без фактической проверки знаний. Предметами взяток явились: три плитки шоколада, бутылка водки и бутылка шампанского. Наказание за содеянное он получил в виде штрафа в размере 35000 рублей.

В первом полугодии 2016 г. следственными подразделениями в средствах массовой информации размещено более 8000 материалов о деятельности ГСУ СК РФ по Красноярскому краю. В средствах массовой информации размещаются материалы о состоянии преступности и мерах по противодействию ей, о расследовании преступлений. Приоритет отдается освещению именно антикоррупционной деятельности. «Несмотря на то, что мы ограничены интересами тайны следствия, - отметил А. Ю. Расстрыгин, - разь- 
яснительную и просветительскую работу стараемся вести с максимальной открытостью».

Тему бытовой коррупции и роли средств массовой информации в ее предупреждении также затронула в своем выступлении И. В. Брежнева, заместитель руководителя Агентства печати и массовых коммуникаций Красноярского края. Высокий предупредительный потенциал информационной деятельности массмедиа является общеизвестным, но вместе с тем содержание распространяемого контента, по мнению докладчика, находится в жесткой зависимости от показателей его популярности среди аудитории. Показательной в этом смысле является следующая статистика. В 2015 г. в 46 государственных средствах массовой информации, учрежденных на территории Красноярского края, выпущен 181 материал, посвященный противодействию коррупции. По результатам мониторинга только два новостных сюжета, вышедших на региональном телеканале «Енисей» и посвященных задержанию должностных лиц по подозрению в совершении коррупционных деяний, вызвали интерес у зрителей. В свою очередь, значительная часть просветительских материалов, которые содержали разъяснения действующего законодательства об идентификации коррупционных отношений и рекомендации о том, как отказаться от вступления в них, оказалась практически не востребованной. Подобная тенденция вызывает ряд проблем, которые наиболее существенно сказываются на антикоррупционной деятельности коммерческих СМИ, поскольку распространять просветительскую информацию становится просто невыгодно.

Предпочтительным выходом из сложившейся ситуации является формирование государственного задания для подведомственных учреждений с учетом потребности в усилении антикоррупционного просвещения населения о формах и видах бытовой коррупции, а также о негативных последствиях совершения коррупционных деяний. Эффективной формой популяризации антикоррупционных материалов, реализуемой на территории Красноярского края, является проведение конкурсов среди средств массовой информации на освещение профилактики коррупции.

И. А. Зайцев, руководитель информационного вещания ОАО «ТВК-6 канал», комментируя предыдущее выступление, подчеркнул, что «на людей не работает абстрактная профилактика. На них абсолютно точно работают релевантные для них примеры. Примеры, которые они могут соотнести с собой. Когда они могут понять, что риск дачи взятки может быть риском для них лично». По мнению докладчика, для аудитории нужны конкретные лица, потому что «обезличенный коррупционер» мало кому понятен.

Одним из специфических способов антикоррупционного просвещения в деятельности средств массовой информации является журналистское расследование. Это достаточно сложный вид журналистской деятельности, который связан с большими финансовыми затратами и высокими юридическими рисками - предпосылками судебных разбирательств. Но, когда журналистские расследования проводятся, крайне важно и для журналиста, и для редакции, и для зрителя понимать ситуацию в развитии; понимать, что это не просто громкие слова, которые однажды сказали и забыли, а что эта история в своем продолжении к чему-то приведет. И здесь актуальным становится взаимодействие с правоохранительными органами, в первую очередь с прокуратурой и следственным комитетом.

Одним из препятствий при проведении журналистских расследований также являются обвинения в заказном характере подобной деятельности. «Для себя лично мы определили очень простой принцип: для нас крайне важно, чтобы та или иная информация, которая нам передается, была правдой», - отметил И. А. Зайцев. Подтвержденность распространяемой информации главный принцип работы любого журналиста.

Журналистские расследования играют большую роль в выявлении и последующем расследовании бытовой коррупции, особенно в сферах образования и здравоохранения. Все чаще граждане, которых принуждают к вступлению в коррупционные отношения, в первую очередь заявляют об этом не в правоохранительные органы, а в средства массовой информации, поскольку не готовы называть свои имена из-за возможных последствий со стороны профессионального сообщества врачей или педагогов. Решить эту проблему, по мнению докладчика, можно лишь совместными усилиями общества и государства.

С. М. Будатаров, канд. юрид. наук, директор Центра антикоррупционных технологий (г. Томск), обратил внимание участников форума на то, что важное значение в осуществлении антикоррупционного просвещения и образования имеет не столько инфор- 
мирование о негативных последствиях коррупции, а также ответственности за совершение коррупционных преступлений, сколько формирование у граждан уважительного отношения к праву и представителям государственной власти. Производя «опыление методом распыления», избрав неправильный подход в образовательной деятельности антикоррупционного содержания, мы рискуем сформировать в обществе не столько нетерпимость к коррупционному поведению, сколько нетерпимость к институту государственной службы в частности и пренебрежение к государственной власти в целом. Приоритетом в деятельности служащего является служение обществу и государству, и примеров честных и бескорыстных государственных деятелей на сегодняшний день достаточно. В процессе антикоррупционного просвещения и образования мы не должны забывать и об их примере.

Опыт антикоррупционного просвещения в сфере закупок представила М. В. Кондратюк, координатор проекта «За честные закупки» Красноярского регионального отделения Общероссийского общественного движения «Народный фронт “За Россию”». По мнению докладчика, просветительская работа в сфере государственной контрактной системы заключается в том, чтобы рассказать гражданам об индикаторах сомнительных закупок и о дальнейших действиях в случае возникновения подозрений о наличии коррупционных отношений. Подобная деятельность в значительной степени способствует активизации общественного контроля.

Заключительным на пленарном заседании стало выступление эксперта из Китайской Народной Республики Пан Дунмэй, канд. юрид. наук, профессора Хэйлунцзянского университета г. Харбина, начальника Центра по изучению российского права. Г-жа Пан отметила, что в Китае антикоррупционное просвещение граждан практически не осуществляется. Основной упор делается на предупреждение и борьбу с коррупцией в государственном управлении. Для обеспечения предупреждения коррупции созданы дисциплинарные комиссии, элементом деятельности которых являются выездные проверки по соблюдению антикоррупционных требований в провинциях, при прокуратуре действует отдел по борьбе с коррупцией и др.

Следующим важным мероприятием в рамках первого дня работы форума стала презентация антикоррупционного просветительского методического комплекса для системы образования Красноярского края. В презентации комплекса участвовали:

И. А. Дамм - канд. юрид. наук, директор Центра противодействия коррупции и правовых экспертиз СФУ, доцент кафедры деликтологии и криминологии Юридического института СФУ;

Е. А. Акунченко - младший научный сотрудник Центра противодействия коррупции и правовых экспертиз СФУ, старший преподаватель кафедры деликтологии и криминологии Юридического института СФУ;

К. С. Сухарева - младший научный сотрудник Центра противодействия коррупции и правовых экспертиз СФУ, ассистент кафедры деликтологии и криминологии Юридического института СФУ.

Первоочередной проблемой, с которой столкнулись эксперты СФУ по противодействию коррупции при реализации положений Программы по антикоррупционному просвещению на 2014-2016 гг. ${ }^{3}$ в образовательной организации, стало отсутствие необходимой научно-методической основы для осуществления антикоррупционного просвещения, а также отсутствие в регионе квалифицированных специалистов в данной области. Анализ проводимых сотрудниками правоохранительных органов просветительских мероприятий показал недостаточно высокую эффективность указанной деятельности ввиду отсутствия у названных субъектов просвещения навыков публичного выступления, а также несоответствия содержания подготовленных лекций целям антикоррупционного просвещения (преобладание статистической отчетности о количестве возбужденных дел коррупционной направленности и показателях привлечения взяточников к уголовной ответственности).

Проанализировав судебную практику, а также результаты мероприятий по антикоррупционному просвещению, проводимому на территории Красноярского края, экспертное сообщество пришло к выводу о необходимости исследовательских и апробационных работ в указанной сфере. СФУ совместно с Красноярским региональным отделением Общероссийской общественной организации «Общество “Знание”

\footnotetext{
3 Об утверждении Программы по антикоррупционному просвещению на 2014-2016 годы: Распоряжение Правительства РФ № 816-р от 14.05.2014 // Собрание законодательства РФ. 2014. № 21. Ст. 2721 .
} 
России» при поддержке Агентства молодежной политики и реализации программ общественного развития Красноярского края реализован проект по разработке и внедрению Антикоррупционного методического просветительского комплекса «Основы антикоррупционного просвещения в сфере образования» [27].

Основная идея проекта заключается в разработке экспертами в области права, педагогики и психологии методического комплекса, достаточного для самостоятельной подготовки лектора (не имеющего специальных познаний в области противодействия коррупции в сфере образования) и проведения им занятия по антикоррупционному просвещению. В рамках просветительской лекции понятный учебный материал, содержащий основную информацию о коррупции, ее негативных последствиях, а также о системе противодействия данному явлению, преподносится аудитории в наглядной, легко запоминаемой форме: в виде схем, житейских сравнений и культурных аллюзий. В содержании методического комплекса использованы видеоразъяснения авторитетных ученых, сотрудников правоохранительных органов, представителей международных организаций, направленные на разрушение основных обывательских стереотипов: «Любой подарок - это не взятка!»; «Шоколадка - это не взятка!»; «Но он же сам предложил!»; «А пусть сначала докажут!» и др.

Как отметила И. А. Дамм, подобные убеждения граждан нередко становятся причиной совершения коррупционных преступлений и правонарушений: «Опыт показывает, что многие преподаватели даже не подозревают, что, например, уголовное законодательство Российской Федерации не определяет минимальный размер взятки. По их мнению, любая получаемая педагогическим работником до, во время или после приема экзамена (зачета) материальная ценность стоимостью менее трех тысяч рублей - это всегда подарок, а взятку образует лишь получение значимого, ценного подарка, но никак не конфет, кофе или коньяка. Также широко распространены представления о том, что учитель свободно может осуществлять репетиторскую деятельность, в том числе у своих собственных учеников, а преподаватель вуза - продавать студентам перед экзаменами свои учебники и пособия. Преодоление таких стереотипов и формирование элементарных знаний о коррупции важные задачи антикоррупционного просвещения».
Антикоррупционный методический просветительский комплекс включает в себя:

- презентацию для проведения просветительского мероприятия в образовательной организации. В ней последовательно раскрываются три основных просветительских модуля: «Коррупция», «Предупреждение коррупции», «Основные коррупциогенные стереотипы». В каждом модуле в простой и доступной форме излагается основной материал, который подкрепляется необходимыми изображениями и схемами. Наиболее сложные вопросы, как, например, разграничение подарка и взятки, минимальный размер взятки, правомерность оказания репетиторских услуг и другие, разъясняются во время видеоконсультаций представителей Прокуратуры Красноярского края, Главного следственного управления Следственного комитета по Красноярскому краю, Федеральной налоговой службы России по Красноярскому краю, докторов юридических наук Юридического института Сибирского федерального университета, Международного института планирования образования ЮНЕСКО;

- учебное пособие для самостоятельной подготовки. Оно призвано помочь лектору подготовиться к проведению занятия по антикоррупционному просвещению без обращения к дополнительной литературе. В пособии сообразно презентации раскрываются основные просветительские модули, но уже с необходимыми теоретическими разъяснениями, нормативными обоснованиями и приведением судебной практики;

- нормативные правовые акты по указанной тематике. В комплексе прилагаются полные тексты необходимых для качественной подготовки к проведению просветительского мероприятия нормативных правовых актов;

- средства наглядной антикоррупционной агитации и пропаганды. Для обеспечения возможности разнообразить свое просветительское занятие лекторам предлагается ряд роликов - победителей конкурсов антикоррупционной социальной рекламы и пропаганды [28].

Содержание комплекса размещено на DVD-Rдиске и распространяется среди представителей системы образования Красноярского края.

Важной особенностью антикоррупционного просветительского методического комплекса является доступность материала, которая позволяет проводить 
просветительскую работу даже тем, кто не имеет юридического образования. В течение четвертого квартала 2016 г. предполагается массовое обучение представителей образовательных организаций, расположенных на территории Красноярского края. В будущем каждый, кто пройдет обучение, сможет проводить просветительские лекции для своих коллег. Эта своеобразная цепная реакция позволит охватить значительный круг граждан, проживающих на территории Красноярского края. Подобная инициатива не имеет аналогов в Российской Федерации.

Завершила насыщенный первый день форума дискуссионная площадка «Антикоррупционное просвещение и антикоррупционное образование как основные формы противодействия коррупции», на которой обсуждались: значимость просвещения и образования; их соотношение с пропагандой, воспитанием, обучением, информированием; содержание форм и методов антикоррупционного просвещения и образования; критерии их эффективности и др.

Второй рабочий день форума был посвящен антикоррупционному образованию, просвещению и информированию государственных (муниципальных) служащих.

Выступления экспертов начались с доклада М. Пуассон об антикоррупционном образовании государственных служащих в зарубежных странах на примере Болгарии, Австрии, Франции и Австралии. Отмечалось, что основной целью образования является формирование и закрепление ценностных ориентиров государственного служащего, исходя из предназначения - служения обществу. Результат образовательных курсов в зарубежных странах - получение необходимых знаний, которые позволят государственным служащим выявлять зоны риска и верно вести себя в сложных ситуациях. Достичь результата позволяют различные образовательные форматы: лекции, семинарские занятия, онлайн-курсы, различные интерактивные форматы и ролевые игры.

О практиках антикоррупционного обучения государственных и муниципальных служащих в Сибирском федеральном округе рассказала Т. В. Алехина, главный советник полномочного представителя Президента Российской Федерации в Сибирском федеральном округе (г. Новосибирск). Основными способами обучения являются: ознакомление с ограничениями, запретами и требованиями, предъявляе- мыми к государственным и муниципальным служащим, ознакомление с базовым законодательством, проведение семинаров, подготовка памяток с положениями законодательства, методических руководств и разъяснений, организация работы методического центра по противодействию коррупции, размещение информации на официальных сайтах органов власти, организация и проведение курсов повышения квалификации. Основными проблемами антикоррупционного обучения являются: отсутствие возможности обеспечить непрерывность образования, отсутствие квалифицированных специалистов для проведения обучения, легкомысленное отношение служащих к вопросам противодействия коррупции и др.

Следующие докладчики: М. П. Романова, заместитель начальника управления - начальник отдела кадров и государственной службы управления кадров и государственной службы Губернатора Красноярского края, и М. А. Калинина, начальник отдела по подготовке государственных и муниципальных служащих (кадрового центра) управления кадров и государственной службы Губернатора Красноярского края, - pacсказали о региональных образовательных программах государственных гражданских служащих. Так, в крае реализуются следующие образовательные программы для государственных и муниципальных служащих: «Антикоррупционная экспертиза нормативных правовых актов и их проектов», «Антикоррупционные механизмы в сфере государственного и муниципального управления», «Противодействие коррупции». Общее количество специальных программ - 11, а образовательных модулей, включенных в иные образовательные программы, -113 . По специальным программам подготовлено 388 служащих. Получили знания в рамках образовательных модулей 4662 служащих. К числу основных проблем антикоррупционного образования докладчики отнесли следующие: отсутствие корреляции результатов проверок, выявляющих значительное число нарушений, с масштабами обучения служащих; отложенный эффект обучения; необходимость не только разьяснения базовых правовых актов, теоретических основ противодействия коррупции и специальных терминов, но и употребление простых и понятных критериев распознавания признаков коррупциогенных ситуаций, «рецептов» поведения в таких ситуациях; необходимость увеличения доли игровых методик обучения; смещение акцента в обучении с «борьбы» 
с нарушителями антикоррупционного законодательства на профилактику и поддержку «здорового» поведения служащих и др.

Об антикоррупционном образовании и просвещении на муниципальном уровне в Красноярском крае выступил А. С. Вишневецкий, начальник экспертно-правового отдела ККГБУ «Институт муниципального развития». Образовательные программы на муниципальном уровне проводятся специалистами ККГБУ «Институт муниципального развития» на безвозмездной основе. Основные мероприятия, проводимые с муниципальными служащими, - это практические занятия, семинары, размещение информационных стендов в органах муниципальной власти, а также размещение информации на официальных сайтах. Кроме того, докладчик обозначил проблемы антикоррупционного образования и просвещения на муниципальном уровне, среди которых труднодоступность отдельных муниципальных образований, недостаточность финансирования и др.

М. А. Верхотурова, прокурор отдела по надзору за исполнением законодательства о противодействии коррупции Прокуратуры Красноярского края, доложила о типичных нарушениях антикоррупционных обязанностей, запретов и ограничений государственными (муниципальными) служащими. Органы прокуратуры края на постоянной основе проводят проверки соблюдения публичными должностными лицами антикоррупционного законодательства. Прежде всего, оцениваются достоверность и полнота представленных ими сведений о доходах и расходах, принятие исчерпывающих мер по предотвращению и урегулированию конфликта интересов.

В 2015 г. выявлено более 10000 нарушений в данной сфере, в первом полугодии 2016 г. - более 6 000. Свыше половины от общего числа выявленных нарушений обнаружены непосредственно в сфере исполнения законодательства о противодействии коррупции, о государственной и муниципальной службе. Значительное количество нарушений выявлено в бюджетной сфере, в сфере оказания государственных и муниципальных услуг, осуществления государственного и муниципального контроля (надзора). Несмотря на ежегодное проведение целевых проверочных мероприятий, число выявленных прокурорами фактов коррупционных нарушений остается высоким. При этом доля нарушений, связанных с представлением сведений о доходах, расходах, в общей массе нарушений запретов, ограничений и обязанностей значительна и составляет более $90 \%$.

В заключение представитель прокуратуры края подчеркнула, что успех антикоррупционной деятельности зависит от результатов работы всех субъектов просветительской деятельности, направленной на создание нетерпимости в обществе к коррупционному поведению.

О ценностях государственной службы в системе противодействия коррупции рассказал Е. А. Бойко, советник директора Сибирского института управления - филиала Российской академии народного хозяйства и государственной службы при Президенте Российской Федерации (г. Новосибирск). Докладчик отметил, что в региональных органах исполнительной власти закрепляются разные ценности, что является неверным и требует унификации, поскольку государственная служба едина везде. Главной профессиональной ценностью служащего должна стать честность. В обоснование своей позиции Е. А. Бойко привел положительный опыт Дании, где при приеме на службу с кандидатом заключается антикоррупционный договор, отказ от подписания которого препятствует поступлению на службу. Выступающий также предложил при осуществлении отбора кадров проводить проверку убеждений и ценностей кандидатов, что позволит избежать попадания на должности государственной службы потенциальных нарушителей антикоррупционных норм.

Следом за выступлениями экспертов последовала дискуссия, на которой обсуждались тезисы докладчиков, проблемы антикоррупционного образования государственных (муниципальных) служащих, содержание деятельности должностных лиц кадровых служб, ответственных за работу по профилактике коррупционных и иных правонарушений, и другие проблемные вопросы.

\section{Выводы}

Два насыщенных образовательных дня были крайне полезными для всех участников форума.

Во-первых, он обнаружил наличие существенных организационных и правовых резервов для совершенствования антикоррупционного просвещения и антикоррупционного образования в современном российском обществе. 
Во-вторых, он указал на механизмы совершенствования систем антикоррупционного просвещения и антикоррупционного образования в России.

В-третьих, обнаружилась и сохраняется потребность в ежегодном проведении Сибирского антикоррупционного форума по тематическим вопросам в сфере противодействия коррупции.

B-четвертых, в силу важности рассматриваемых на форуме вопросов возникла необходимость предоставления результатов II Сибирского антикоррупционного форума широкому кругу заинтересованных лиц в це- лях совершенствования систем антикоррупционного просвещения и антикоррупционного образования не только в Сибирском федеральном округе, но и на территории всей Российской Федерации.

Как отметил в заключительном слове профессор Н. В. Щедрин, «коррупция - это не тот дракон, который летает вокруг нас. Коррупция - это тот червячок, который живет в каждом из нас». И справиться с ней можно лишь путем кропотливой работы каждого члена общества прежде всего над собой: коррупция непобедима, пока все проходят мимо 4

\section{Список литературы}

1. Абрамов Р. А. Вопросы формирования антикоррупционного мировоззрения в обществе // Актуальные проблемы экономики и права. 2014. № 2. С. 178-187.

2. Бикеев И. И., Кабанов П. А. Антикоррупционное образование в России: состояние и перспективы // Бизнес. Образование. Право. Вестник Волгоградского института бизнеса. 2010. № 3. С. 178-188.

3. Воронцов С. А. Об организации антикоррупционного просвещения в Российской Федерации // Северо-Кавказский юридический вестник. 2015. № 1. С. 105-111.

4. Гарипов И. М. Виктимологические аспекты антикоррупционного образования в современной России // Следователь. 2010. № 8. С. 13-14.

5. Гармаев Ю. П., Фалилеев В. А. Реализация мер антикоррупционного просвещения органами прокуратуры во взаимодействии с юридическими вузами // Государственная власть и местное самоуправление. 2015. № 1. С. 11-15.

6. Зинатуллин 3. 3. Нравственность, профессионализм, правовое просвещение как антикоррупционные детерминанты // Восточно-Европейский научный вестник. 2016. № 3. С. 28-30.

7. Кабанов П. А. Антикоррупционное информирование как форма антикоррупционного просвещения: понятие и содержание // Мониторинг правоприменения. 2015. № 2. С. 40-46.

8. Кабанов П. А. Антикоррупционное консультирование как разновидность антикоррупционного просвещения: понятие и содержание // Административное и муниципальное право. 2015. № 6. С. 634-642.

9. Кабанов П. А. Антикоррупционное просвещение в субъектах Российской Федерации: опыт правового регулирования организации и перспективы развития // NB: Административное право и практика администрирования. 2016. № 4. С. 35-55.

10. Кабанов П. А. Антикоррупционное просвещение как средство противодействия коррупции: понятие и содержание // Актуальные проблемы экономики и права. 2014. № 4. С. 42-51.

11. Кабанов П. А. О соотношении антикоррупционного образования и антикоррупционного просвещения как видов антикоррупционной деятельности // Административное и муниципальное право. 2015. № 9. С. 978-985.

12. Кабанов П. А. Понятие антикоррупционной рекламы как правовой категории: региональный аспект // Административное и муниципальное право. 2013. № 11. С. 1048-1049.

13. Кабанов П. А. Понятие и содержание антикоррупционного просвещения как средства профилактики коррупции // Юридические исследования. 2015. № 2. С. 12-27.

14. Кабанов П. А. Система количественных показателей результативности антикоррупционного просвещения как инструмента противодействия коррупции: правовое регулирование и классификация // Административное и муниципальное право. 2015. № 8. С. 853-864.

15. Козлова Е. Б. Проблемы формирования и реализации региональной политики антикоррупционного просвещения на современном этапе // Правовая культура. 2016. № 4. С. 17-25.

16. Слюсарева Т. Г. Антикоррупционное просвещение как эффективное направление в борьбе с коррупцией // Научный вестник Невинномысского государственного гуманитарно-технического института. 2015. № 4. С. 18-22.

\footnotetext{
${ }^{4}$ Слоган - победитель конкурса антикоррупционной социальной рекламы, проведенного Антикоррупционным студенческим клубом СФУ в 2010 г. [29].
} 
17. Сюзева Н. В. О преодолении деформаций правового сознания в процессе антикоррупционного образования // Право и образование. 2014. № 4. С. 34-41.

18. Трунцевский Ю. В. Организация антикоррупционного просвещения как одно из направлений правоохранительной деятельности по профилактике коррупции // Юридическое образование и наука. 2015. № 3. С. 36-38.

19. Фалилеев В. А. Правовое просвещение как средство предупреждения коррупции в регионе // Государственная власть и местное самоуправление. 2012. № 10. С. 3-5.

20. Хайрутдинова Л. Р. Антикоррупционное консультирование: понятие, виды и содержание // Политика, государство и право. 2015. № 6. С. 58-60.

21. Хайрутдинова Л. Р. Антикоррупционное просвещение: понятие, цели и значение // Гуманитарные научные исследования. 2015. № 1-1. С. 106-109.

22. Шедий М. В. Формирование антикоррупционного правосознания как основного элемента антикоррупционного образования гражданского общества // Вестник университета (Государственный университет управления). 2014. № 3. С. 286-290.

23. Шугрина Е. С. Понятие и признаки коррупции: особенности правового просвещения учащихся // Административное право и процесс. 2015. № 6. С. 54-57.

24. Юсупов М. Р. Антикоррупционное просвещение в России - апологет правовой грамотности // Властная вертикаль Федерации. 2015. № 2-3. С. 5.

25. Аллак Ж., Пуассон М. Коррумпированные школы, коррумпированные университеты: Что можно сделать?. Париж: Международный Институт планирования образования ЮНЕСКО, 2014. 365 с.

26. Heidenheimer A. Campaign Finance and Political Corruption: Tracing Long-Term Comparative Dynamics. Paper presented at the XVIII World Congress of the IPSA. Quebec City, 2000. August 1-5.

27. Основы антикоррупционного просвещения в сфере образования: учеб. пособие / Е. А. Акунченко, П. А. Вырва, И. А. Дамм и др.; под. ред. И. А. Дамм, Н. В. Щедрина. Красноярск: Сиб. федер. ун-т, 2016. 200 с.

28. Дамм И. А. Антикоррупционное просвещение в сфере образования в Красноярском крае // Актуальные вопросы противодействия коррупции в субъектах Российской Федерации: материалы научно-практ. конференции. Казань, 2016. С. 246-251.

29. Высшее образование - не место для коррупции: учеб. пособие / под ред. И. А. Зыряновой. Красноярск: ЮИ СФУ, 2010. $30 \mathrm{c}$.

\section{References}

1. Abramov R. A. Issues of forming the anticorruption worldview in the society, Aktual'nye problemy ekonomiki i prava, 2014, No. 2, pp. 178-187 (in Russ.).

2. Bikeev I. I., Kabanov P. A. Anticorruption education in Russia: state and prospects, Biznes. Obrazovanie. Pravo. Vestnik Volgogradskogo instituta biznesa, 2010, No. 3, pp. 178-188 (in Russ.).

3. Voroncov S. A. On organization of anticorruption enlightenment in the Russian Federation, Severo-Kavkazskij juridicheskij vestnik, 2015, No. 1, pp. 105-111 (in Russ.).

4. Garipov I. M. Victimological aspects of anticorruption education in modern Russia, Sledovatel', 2010, No. 8, pp. 13-14 (in Russ.).

5. Garmaev Ju. P., Falileev V. A. Implementation of anticorruption enlightenment measures by prosecutor's office bodies in interaction with juridical universities / Ju. P. Garmaev, V. A. Falileyev, Gosudarstvennaja vlast'i mestnoe samoupravlenie, 2015, No. 1, pp. 11-15 (in Russ.).

6. Zinatullin Z. Z. Morals, professionalism, legal enlightenment as anticorruption determinants, Vostochno-Evropejskij nauchnyj vestnik, 2016, No. 3, pp. 28-30 (in Russ.).

7. Kabanov P. A. Anticorruption informing as a form of anticorruption enlightenment: notion and content, Monitoring pravoprimenenija, 2015, No. 2, pp. 40-46 (in Russ.).

8. Kabanov P. A. Anticorruption consulting as a form of anticorruption enlightenment: notion and content, Administrativnoe $i$ municipal'noe pravo, 2015, No. 6, pp. 634-642 (in Russ.).

9. Kabanov P. A. Anticorruption enlightenment in the Russian Federation subjects: experience of legal regulation of organization and prospects of development, NB: Administrativnoe pravo i praktika administrirovanija, 2016, No. 4, pp. 35-55 (in Russ.).

10. Kabanov P. A. Anticorruption enlightenment as a means of corruption counteraction: notion and content, Aktual'nye problemy ekonomiki i prava, 2014, No. 4, pp. 42-51 (in Russ.).

11. Kabanov P. A. On the coordination of anticorruption education and anticorruption enlightenment as types of anticorruption activity, Administrativnoe i municipal'noe pravo, 2015, No. 9, pp. 978-985 (in Russ.).

Щедрин Н. В., Дамм И. А., Акунченко Е. А. Актуальные проблемы антикоррупционного просвещения и антикоррупционного образования Shchedrin N. V., Damm I. A., Akunchenko E. A. Topical issues of anticorruption enlightenment and anticorruption education 
12. Kabanov P. A. Notion of anticorruption advertisement as legal category: regional aspect, Administrativnoe i municipal'noe pravo, 2013, No. 11, pp. 1048-1049 (in Russ.).

13. Kabanov P. A. Notion and content of anticorruption enlightenment as a means of corruption prevention, Juridicheskie issledovanija, 2015, No. 2, pp. 12-27 (in Russ.).

14. Kabanov P. A. System of quantitative indicators of efficiency of anticorruption enlightenment as a means of corruption counteraction: legal regulation and classification, Administrativnoe i municipal'noe pravo, 2015, No. 8, pp. 853-864 (in Russ.).

15. Kozlova E. B. Issues of financing and implementation of the regional policy of anticorruption enlightenment at the modern stage, Pravovaja kul'tura, 2016, No. 4, pp. 17-25 (in Russ.).

16. Sljusareva T. G. Anticorruption enlightenment as an effective area of corruption counteraction, Nauchnyj vestnik Nevinnomysskogo gosudarstvennogo gumanitarno-tehnicheskogo instituta, 2015, No. 4, pp. 18-22 (in Russ.).

17. Sjuzeva N. V. On overcoming the deformation of legal consciousness in the process of anticorruption education, Pravo $i$ obrazovanie, 2014, No. 4, pp. 34-41 (in Russ.).

18. Truncevskij Ju. V. Organization of anticorruption enlightenment as one of the areas of law-enforcement activity for corruption prevention, Juridicheskoe obrazovanie i nauka, 2015, No. 3, pp. 36-38 (in Russ.).

19. Falileev V. A. Legal enlightenment as a means of corruption prevention in a region, Gosudarstvennaja vlast' $i$ mestnoe samoupravlenie, 2012, No. 10, pp. 3-5 (in Russ.).

20. Hajrutdinova L. R. Anticorruption consulting: notion, types and content, Politika, gosudarstvo i pravo, 2015, No. 6, pp. 58-60 (in Russ.).

21. Hajrutdinova L. R. Anticorruption enlightenment: notion, aims and significance, Gumanitarnye nauchnye issledovanija, 2015, No. 1-1, pp. 106-109 (in Russ.).

22. Shedij M. V. Forming the anticorruption legal consciousness as the main element of anticorruption education of the civil society, Vestnik universiteta (Gosudarstvennyj universitet upravlenija), 2014, No. 3, pp. 286-290 (in Russ.).

23. Shugrina E. S. Notion and signs of corruption: features of legal enlightenment of students, Administrativnoe pravo i process, 2015, No. 6, pp. 54-57 (in Russ.).

24. Jusupov M. R. Anticorruption enlightenment in Russia - an apologetics of legal competence, Vlastnaja vertikal'Federacii, 2015, No. 2-3, p. 5 (in Russ.).

25. Hallak J., Poisson M. Corrupt schools, corrupt universities: What can be done?, Parizh: Mezhdunarodnyj Institut planirovanija obrazovanija JuNESKO, 2014, 365 p. (in Russ.).

26. Heidenheimer A. Campaign Finance and Political Corruption: Tracing Long-Term Comparative Dynamics. Paper presented at the XVIII World Congress of the IPSA. Quebec City, 2000. August 1-5.

27. Akunchenko E. A., Vyrva P. A., Damm I. A. et al. Bases of anticorruption enlightenment in the sphere of education, Krasnoyarsk: Sib. feder. un-t, 2016. 200 p. (in Russ.).

28. Damm I. A. Anticorruption enlightenment in the sphere of education in Krasnoyarsk krai, Topical issues of corruption counteraction in the Russian Federation subjects: work of scientific-practical conference, Kazan, 2016, pp. $246-251$ (in Russ.).

29. Higher education is not the place for corruption / ed. I. A. Zyrjanova, Krasnoyarsk: JuI SFU, 2010, 30 p. (in Russ.).

\section{Информация об авторах}

\section{Контактное лицо:}

Щедрин Николай Васильевич, доктор юридических наук, профессор, профессор кафедры деликтологии и криминологии Юридического института, Сибирский федеральный университет

Адрес: 660075, Красноярский край, г. Красноярск, ул. Маерчака, 6, тел.: +7 (391) 206-23-28

E-mail: sveroboy@mail.ru

ORCID: http://orcid.org/0000-0001-8226-9449

Researcher ID: http://www.researcherid.com/rid/H-6444-2017 
Дамм Ирина Александровна, кандидат юридических наук, директор Центра противодействия коррупции и правовых экспертиз, Сибирский федеральный университет

Адрес: 660075, Красноярский край, г. Красноярск, ул. Маерчака, 6, тел.: +7 (391) 206-23-28

E-mail: idamm@sfu-kras.ru

ORCID: http://orcid.org/0000-0001-6286-374X

Researcher ID: http://www.researcherid.com/rid/P-6433-2016

Акунченко Евгений Андреевич, младший научный сотрудник Центра противодействия коррупции и правовых экспертиз, Сибирский федеральный университет

Адрес: 660075, Красноярский край, г. Красноярск, ул. Маерчака, 6, тел.: +7 (391) 206-23-28

E-mail: eakunchenko@sfu-kras.ru

ORCID: http://orcid.org/0000-0002-9030-7422

Researcher ID: http://www.researcherid.com/rid/N-1511-2017

\section{Information about the authors}

Contact:

Nikolay V. Shchedrin, Doctor of Law, Professor, Professor of the Department of Delictology and Criminology of the Law Institute of Siberian Federal University

Address: 6 Mayerchak str., 660075, Krasnoyarsk krai, Krasnoyarsk, tel.: +7 (391) 206-23-28

E-mail: sveroboy@mail.ru

ORCID: http://orcid.org/0000-0001-8226-9449

Researcher ID: http://www.researcherid.com/rid/H-6444-2017

Irina A. Damm, PhD (Law), Director of the Center for Corruption Counteraction and Legal Expertise, Siberian Federal University Address: 6 Mayerchak str., 660075, Krasnoyarsk krai, Krasnoyarsk, tel.: +7 (391) 206-23-28

E-mail: idamm@sfu-kras.ru

ORCID: http://orcid.org/0000-0001-6286-374X

Researcher ID: http://www.researcherid.com/rid/P-6433-2016

Evgeniy A. Akunchenko, Junior Researcher of the Center for Corruption Counteraction and Legal Expertise, Siberian Federal University

Address: 6 Mayerchak str., 660075, Krasnoyarsk krai, Krasnoyarsk, tel.: +7 (391) 206-23-28

E-mail: eakunchenko@sfu-kras.ru

ORCID: http://orcid.org/0000-0002-9030-7422

Researcher ID: http://www.researcherid.com/rid/N-1511-2017

Щедрин Н. В., Дамм И. А., Акунченко Е. А. Актуальные проблемы антикоррупиионного просвещения и антикоррупиионного образования Shchedrin N. V., Damm I. A., Akunchenko E. A. Topical issues of anticorruption enlightenment and anticorruption education 